\title{
Exploration and Practice of Cultivating Creative, Innovative and Entrepreneurial Ability of E-commerce Talents
}

\begin{abstract}
XiaoLan Feng
School of Engineering and Technology, Xi'an Fanyi University, Xi'an

25345112@qq.com

ABSTRACT

The new engineering construction of the Ministry of Education clearly points out the new requirements of creative innovation and entrepreneurship training in engineering specialty construction. Meanwhile, with the rapid development of e-commerce, as a practical e-commerce major, it must also highlight the cultivation of students' "three innovations" ability. Combined with the existing problems of "three innovation" ability training in e-commerce major, this paper puts forward the goals and ideas of e-commerce talent training under the background of new engineering, and points out the implementation of reform and innovation from the aspects of school-enterprise collaborative education, curriculum system, assessment content and methods, innovation and entrepreneurship platform and teaching staff construction.
\end{abstract}

Keywords: the new engineering; creativity; Innovation and entrepreneurship; e-commerce professional talent training.

\section{INTRODUCTION}

Since 2017, the Ministry of Education has actively promoted the construction of new engineering and clearly pointed out the new requirements for the cultivation of creativity, innovation and entrepreneurship in the construction of engineering majors [4]. The construction of new engineering requires that the engineering talents trained by universities must have a new way of thinking under the background of the new economy, especially the consciousness and ability of innovation and entrepreneurship [3]. In recent years, with the introduction of relevant policies and social needs, colleges and universities have attached great importance to the training of "three innovation" talents.

Due to the rapid development and application of e-commerce, "Internet + " business model has appeared in all walks of life. However, the cultivation of e-commerce talents in colleges and universities does not meet the market demand, so there is a huge gap in the demand for e-commerce talents. The cultivation of creative thinking, innovative consciousness and entrepreneurial ability of e-commerce talents is an important problem faced by colleges and universities under the background of new engineering. Colleges and universities should give full play to the role of engineering education in cultivating e-commerce talents, promote the "three innovation" education to run through and integrate into professional education, and focus on cultivating students' creative thinking, innovative consciousness and entrepreneurial ability.

\section{THE MAIN PROBLEMS EXISTING IN THE CULTIVATION OF E-COMMERCE TALENTS}

\subsection{The positioning of creativity, innovation and entrepreneurship in talent training is not clear}

Many colleges and universities often neglect the important role of "three innovations" in talent training when setting the goal of cultivating students majoring in e-commerce. The rapid development of e-commerce industry, talent demand gap is huge. According to the 2019 China E-commerce talent survey report, 8 percent of e-commerce enterprises have a talent gap, and nearly 30 percent have large-scale recruitment plans. However, there is a shortage of innovative and entrepreneurial 
talents who are both familiar with the business knowledge of the industry and proficient in network information technology, which puts forward new requirements for the teaching of e-commerce in colleges and universities. It is very necessary to innovate the teaching mode in line with the needs of modern society.

\subsection{School-enterprise collaborative education is not in-depth}

The effective implementation of "three innovation" education cannot be accomplished by universities alone. Universities must actively cooperate with enterprises on the basis of research, give full play to their respective strengths, learn from each other, and integrate the theory of innovation and entrepreneurship with practice. Colleges and universities can integrate educational resources and promote the cultivation of innovative and entrepreneurial talents by implementing the professional construction mode of "university-enterprise cooperation and collaborative education". However, there are many problems in the current school-enterprise cooperation, such as insufficient understanding between the two sides and lack of in-depth cooperation; Imperfect system leads to unsustainable cooperation; Poor cooperation affects talent cultivation. In the integration of industry and education, universities pay attention to enterprises' support for employment, but ignore enterprises' support for innovation and entrepreneurship education.

\section{THE TRAINING IDEA OF "THREE INNOVATION" ABILITY OF E-COMMERCE TALENTS UNDER THE NEW ENGINEERING BACKGROUND}

It is a profound change to carry out "three innovation" education in the reform of talent training mode. Because it involves many aspects, such as: change the concept of talent training, innovation of teaching methods, reform of teaching quality evaluation system. Therefore, e-commerce professional to "creative thinking, innovation and entrepreneurship" talent training goal, actively explore innovative entrepreneurial talent training mode, build to synergy between higher vocational colleges education, optimizing the course system, strengthening the construction of teaching staff, reforming the content of the assessment methods, strengthening innovative entrepreneurial platform "as the main content of the education system. The cultivation idea is shown in Figure 1.

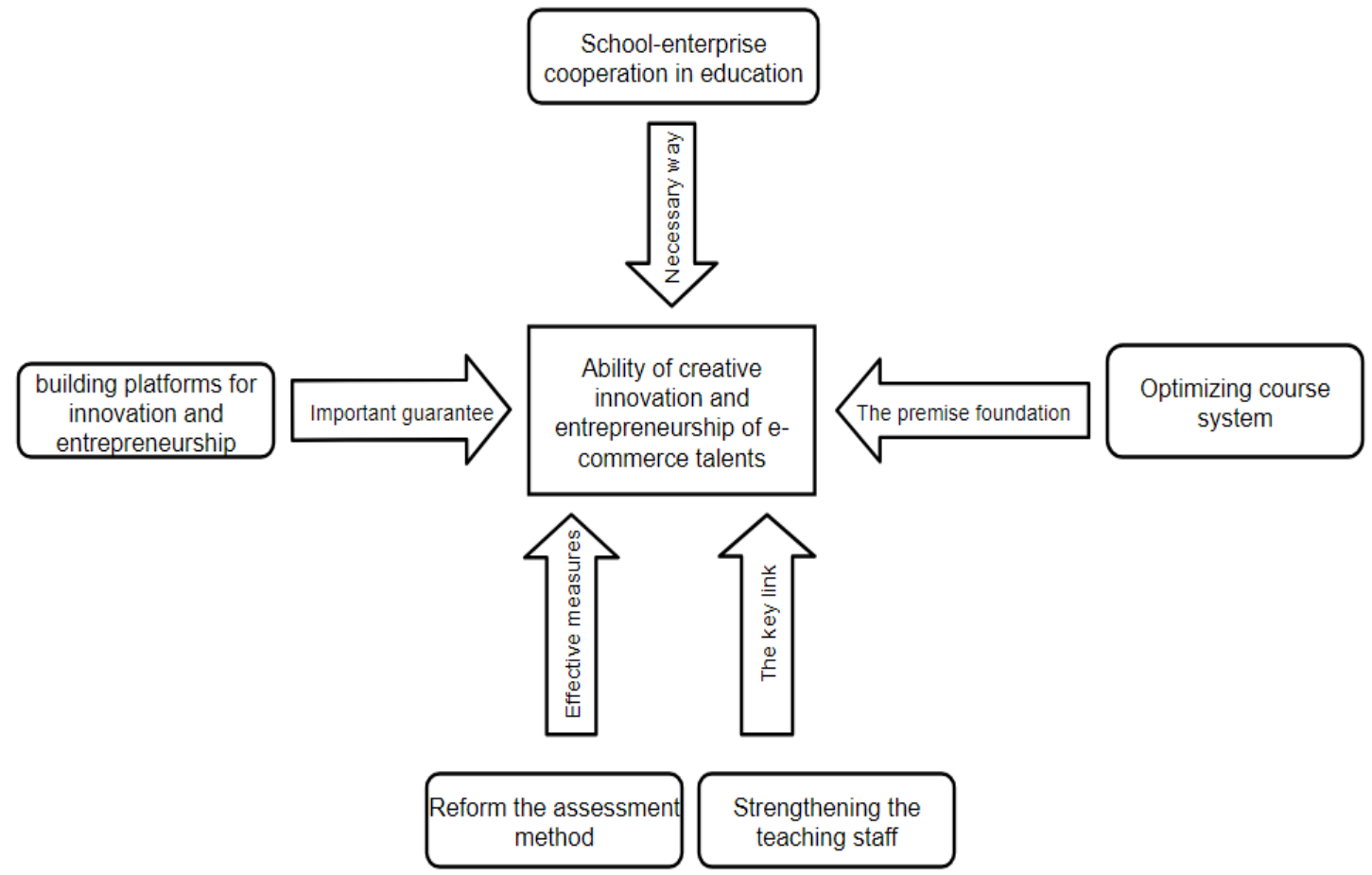

Figure 1. Training ideas of "three innovation" ability of e-commerce talents 


\section{TRAINING PRACTICE OF "THREE INNOVATION" ABILITY OF E-COMMERCE TALENTS UNDER THE NEW ENGINEERING BACKGROUND}

\subsection{We will vigorously promote school-enterprise cooperation in educating students}

The teaching team collaborates with Many enterprises such as Shaanxi Staffordshire Business Incubation Center, $\mathrm{Xi}$ 'an Shengyuan E-commerce Company, Shaanxi Prime Power Information Technology Research Institute and so on to develop e-commerce professional talent training programs, making them more scientific and reasonable. Through the deep cooperation with Alibaba Northwest branch, Shanxi Hard Man Network Technology Co., Ltd. and other enterprises, the direct connection with employers is realized. Guided by industrial demand, establish a long-term mechanism of industry-university-research cooperation and education, and build engineering innovation training center with enterprises.

Many enterprises have taken the initiative to establish long-term employment relationship with our school, and the employment rate of students has increased year by year. In 2020, the employment rate of students is over $95 \%$, and the employment rate of professional counterparts is $93.7 \%$. The overall satisfaction of graduates increases year by year and is well received by employers. After graduation, there are 10 successful entrepreneurs and 6 registered companies within 3 years, and the operation is in good condition. The comparison of student employment rate, counterpart employment rate and entrepreneurship rate in the past three years is shown in Figure 2.

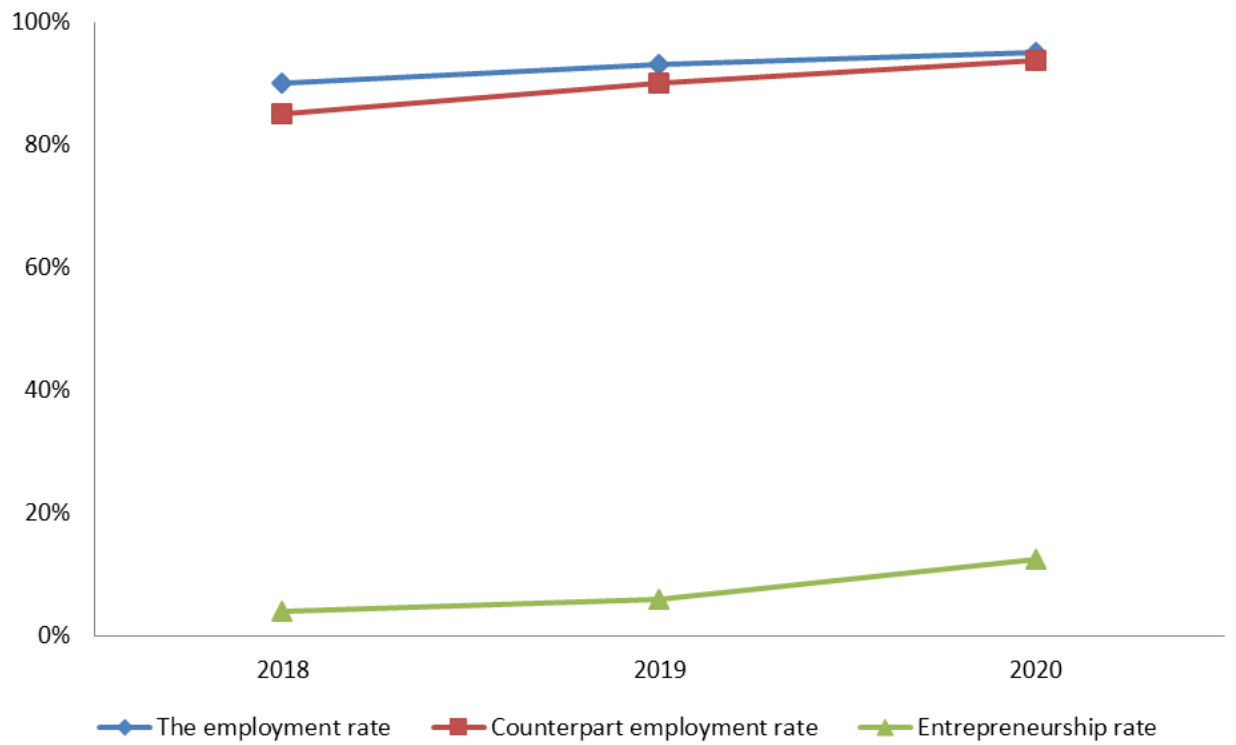

Figure 2: Curve comparison diagram

\subsection{Optimize the curriculum system and teaching methods}

Centering on "learning, using and creating", deepen classroom revolution [2] and integrated teaching reform, make use of the advantages of new media resources, optimize teaching resources, standardize teaching work, build a teaching mode combining offline and online, and improve teaching quality. In the past three years, there have been 9 course construction projects, including 1 provincial high-quality online open course, 6 school-enterprise cooperative education projects, and 7 new courses reformed as process examinations. Adopt heuristic and interactive teaching mode to improve teaching effect. $80 \%$ of the main courses have realized flipped classroom, which focuses on giving play to students' active participation and team spirit, and developing different thinking and divergent thinking.

According to the construction principle of integration of theory and practice, and integration of teaching, learning and doing, to create a characteristic practical teaching platform. Highlight the guiding role of OBE concept, pay attention to cross integration and resource sharing, cultivate high quality, strong ability, great potential and application of e-commerce senior professionals, develop e-commerce professional practice teaching system. The teaching reform process based on OBE concept is shown in Figure 3. 


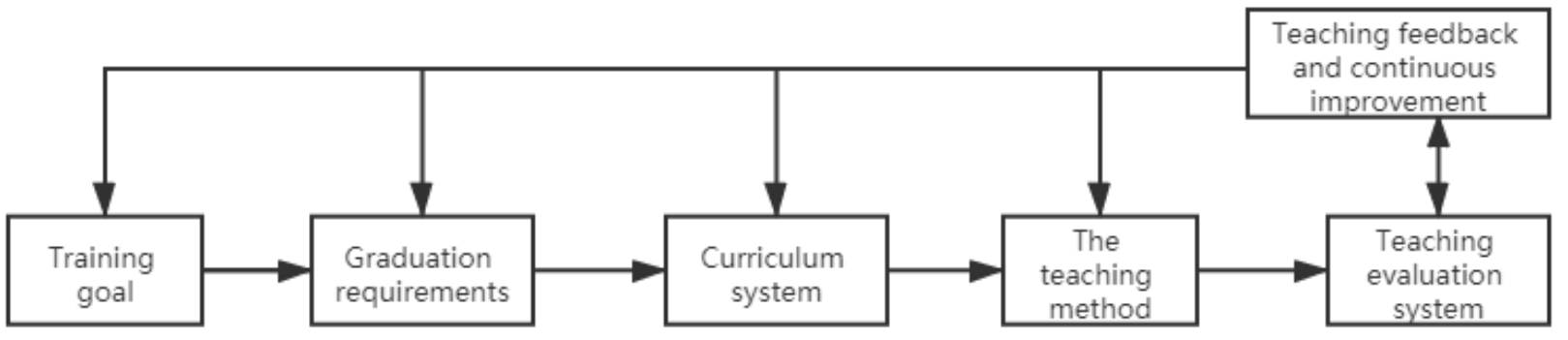

Figure 3 Flow chart of teaching reform process based on OBE concept

\section{3. reform the content and methods of assessment}

The teaching team focuses on the ability of students to comprehensively use knowledge to analyze and solve innovation and entrepreneurship problems. According to the requirements of the teaching syllabus and the standards of vocational positions and innovation and entrepreneurship ability, the team carries out theoretical and practical assessment in cooperation with cooperative enterprises. The assessment proportion is $20 \%$ for innovation and entrepreneurship assessment, $20 \%$ for enterprise assessment, 20\% for classroom assessment and $40 \%$ for final assessment, forming the "2224 mode".

The credit accumulation and conversion system for innovation and entrepreneurship, various innovation and entrepreneurship competitions and credit mutual recognition system are proposed to allow students to adjust their academic process appropriately. For example, students are encouraged to retain their school status and suspend their study to start their own business if their entrepreneurial projects obtain external investment.

\subsection{We will strengthen platforms for innovation and entrepreneurship}

On the basis of deepening school-enterprise cooperation, enterprises are introduced into the school, projects are introduced into the industrial park, and technologies are introduced into the classroom. This continuous deepening of the "three steps" has realized the scene-based professional teaching, modular curriculum and expert teaching team, which greatly improves the students' ability of "three innovation".

The school continues to promote and improve discipline competitions. All students participate in discipline and professional competitions and apply for innovation projects in the form of team, realizing the transformation of innovative talent training mode of "promoting innovation through competition and combining innovation with competition". Under the guidance of the university mentors and corporate mentors, students have participated in the National College Students e-commerce "Three Innovation
Competition", "Internet + " College students Entrepreneurship Competition, Discovery Cup Internet + Competition, New Media Design Competition and other discipline competitions. More than 40 teachers have won the provincial and ministerial level "Excellent Advisor", and more than 300 students have won awards.

In 2018, the College established e-commerce Innovation Industrial Park, which became the first cross-border e-commerce talent training base in northwest China, and solved the problem of lack of real enterprise project practice and operation in e-commerce talent training. Students carry out real cross-border e-commerce operation projects and domestic e-commerce projects in the industrial park, realizing the combination of simulated operation and real operation, greatly improving students' learning enthusiasm, e-commerce operation ability and innovation and entrepreneurship ability. Every year, in addition to e-commerce majors, other majors such as international trade, business English, French and other minor language majors also enter the industrial park for training and learning.

\subsection{We will strengthen the teaching staff}

The college takes "double teachers" quality and "double teachers" structure as the core, and aims to improve the teaching ability of the teaching staff. Using the principle of "internal training and external introduction", the college introduces outstanding technical personnel from enterprises, adjusts the structure of the teaching staff, and improves the overall quality. Strengthen the cultivation of teachers' innovation and entrepreneurship awareness and ability, and take innovation and entrepreneurship as the main content of training; Encourage young teachers to study and practice in e-commerce enterprises; Encourage teachers and enterprise personnel to carry out teaching and research together. Every year, 1-2 young teachers majoring in e-commerce in our school should take temporary positions in e-commerce enterprises to participate in enterprise project operation learning and research [5].

At the same time, the college invites the technical personnel in the front line of enterprises to teach professional practice courses to improve the level of 
practice teaching. We invite industry experts to our school to give professional lectures. For example, every year we invite Professor Li Qi to give lectures on "three innovation" ability cultivation. Invite entrepreneurs with entrepreneurial experience or successful alumni to guide students' innovation and entrepreneurship projects, and guide students who have entrepreneurial ideas or have started their own businesses to improve the success rate of entrepreneurship.

\section{CONCLUSIONS}

"Mass entrepreneurship and innovation". With the rapid development of e-commerce and the new requirements of major construction under the background of new engineering, the construction of e-commerce major in colleges and universities emphasizes the cultivation of "creative thinking, innovative consciousness and entrepreneurial ability", giving full play to the role of engineering education in the cultivation of e-commerce talents. At the same time, it also conforms to the professional characteristics of e-commerce and the market demand of e-commerce industry application. The training of "three innovation" ability encourages e-commerce students to open up their thinking, improve their practical ability, create good opportunities for innovation and entrepreneurship, form a real innovation and entrepreneurship spirit, and lay a solid foundation for future employment and entrepreneurship.

\section{ACKNOWLEDGMENTS}

This paper is the phased achievement of the 2020 annual project of the 13th Five-Year Plan of Education science in Shaanxi Province (SGH20Y1515). Periodical achievements of the provincial first-class professional construction project of Xi 'an Institute of Translation and Interpreting.

\section{REFERENCES}

[1] Zhu,K.J., Chen, Z.G., Luo,B.G. (2020) Research on talent training and Evaluation of new engineering "Triple Innovation and Integration". Internet of Things Technology, 7: 119-120.

[2] Feng,X.L. (2020) Exploration and Practice of cross-border E-commerce talent Training Path from the perspective of supply-side Structural reform. Business News,8: 184-185.

[3] Lou,L.Y. (2020) Innovation and Entrepreneurship of new engineering Talents: Exploration and Practice. Science, Technology and Economy Guide,18: 137-138.

[4] Zhang,M.,Wang,H.L. (2019) Research on the cultivation of innovative and entrepreneurial talents in local universities under the background of new engineering. Education Modernization,10: 28-30.

[5] Wang Z.H. (2018) Exploration of School-enterprise Collaborative Cultivation of E-commerce Innovative and Entrepreneurial Talents -- Taking E-commerce major of Xi 'an Translation University as an example. Journal of Guangxi Radio and TELEVISION University, 3:54-57 